\title{
Proceeding
}

Supplementary Issue: Spring Conferences of Sports Science. Costa Blanca Sports Science Week, 26-28 April 2018. Calpe. Alicante, Spain

\section{Leadership in sport: Study with futsal coaches in "Under 17" and senior levels}

SAMUEL HONÓRIO $1 \checkmark$, MARCO BATISTA ${ }^{1}$, JOÃO SERRANO ${ }^{1}$, JOÃO PETRICA ${ }^{1}$, JORGE SANTOS ${ }^{1}$, JÚLIO MARTINS ${ }^{2}$, DIOGO INÊS ${ }^{3}$, FILIPE SOARES ${ }^{4}$

${ }^{1}$ SHERU (Sport, Health and Exercise Research Unit), Instituto Politécnico de Castelo Branco, Castelo Branco, Portugal

2Universidade da Beira Interior, CIDESD, Covilhã, Portugal

${ }^{3}$ Vitória Clube de Santarém, Portugal

${ }^{4}$ Piaget Institute, Almada, Portugal

\begin{abstract}
Introduction: The leader, in the coach role, must be able to relate and establish connections with his athletes, and contribute to the construction of an environment conducted by fair and clear norms that do not oppose the organizational culture of the club (Lopes, 2008; Mendo \& Ortiz, 2003). Objective: The objective of this research was to identify the leadership behaviours of two coaches from different levels (Under 17 and Seniors), as well as the perception of leadership behaviours of their players. Methodology: The sample consisted of two coaches and 26 players, 12 of them in the "Under 17" level aged between 15 and 17 years, and 14 senior players, aged between 18 and 33 years. We used the Leadership Scale for Sports (LSS) / Leadership Scale in Sport, by Chelladurai \& Saleh (1978). In this descriptive and inferential study, the Kolmogrov-Smirnov test was performed for the normality assumptions by choosing the parametric statistic and to analyse the differences between the variables, a Student-T test was performed. Five dimensions were analysed: Training Instruction, Social Support, Reinforcement, Democratic Behaviour and Autocratic Behaviour. The results obtained showed significant differences between the coach's self-perception and the players' perception, as well as their preferences and their comparison between levels. According to coaches, the dimension of training instruction and reinforcement, are the styles of leadership with more emphasis and

Corresponding author. SHERU (Sport, Health and Exercise Research Unit); Instituto Politécnico de Castelo Branco, Castelo Branco, Portugal.

E-mail: samuelhonorio@ipcb.pt

Supplementary Issue: Spring Conferences of Sports Science. Costa Blanca Sports Science Week, 26-28 April 2018. Calpe. Alicante, Spain.

JOURNAL OF HUMAN SPORT \& EXERCISE ISSN 1988-5202

(c) Faculty of Education. University of Alicante

doi: 10.14198/jhse.2018.13.Proc2.18
\end{abstract}


the smaller is the autocratic. Key words: LEADERSHIP, FUTSAL, SELF-PERCEPTION, PERCEPTION, PREFERENCES.

\section{Cite this article as:}

Honório, S., Batista, M., Serrano, J., Petrica, J., Santos, J., Martins, J., Inês, D., \& Soares, F. (2018). Leadership in sport: Study with futsal coaches in "Under 17" and senior levels. Journal of Human Sport and Exercise, 13(2proc), S339-S350. doi:https://doi.org/10.14198/ihse.2018.13.Proc2.18 


\section{INTRODUCTION}

Team sports are characterized by the relations established between the players, whether of collaboration or of opposition, in a given context to reach a certain final objective. In this perspective there are fundamental behaviours of dialogue that allow to develop the dynamics between the players of the same team, under the opposition of the other teal players. In this relationship of strengths, a balance between the roles to be performed by each player, within a collective organization, and the capacity of each one to explore the game context becomes essential (Travassos \& Araújo, 2005). The exploration of the game context has great variability, but it is not random, as it aims to achieving the team's goal for the game. To achieve the team objective, it implies creativity in the actions of the game, to unbalance the opponent, even during defensive processes (Travassos \& Araújo, 2005). Although Futsal has a more recent appearance and development, the dynamic organization and its purpose is similar to soccer, there are differences in some game laws and regulations that vary with space and game elements (Casarin, 2010). In these sports the players' performance is related to the capacity to respond effectively, through the appeal to the decision and strategic capacity, to the constant situational changes in which the game takes place. The responses to these situations are supported by individual actions, in a collective project, whose behaviour is influenced by the antagonistic relations of attack/defense (Castelo, 2009). Team sports are characterized by discontinuous, intermittent and intense physical exercises in which running and rest periods alternates with continuous jumps or continuous low-intensity running, (Dias, 2011), in which Futsal is included. At present, we are increasingly looking for a specific characterization for each sport practiced, both in individual and collective sports so that coaches can prepare their athletes according to the specific requirements of each sport (Dias, 2011).

Sampedro (1998) considers Futsal as a complex and dynamic activity, due to the multiplicity of dimensions that directly affect the motor action and the development of the game process. According to Amaral and Garganta (1995), the call for cooperation between team members with a view to overcoming opposition from opposing teams and the appeal to intelligence as a capacity to adapt to a constantly changing context constitute two of the main principles of this sports. Futsal is a sport that presents characteristics of highintensity and short-duration physical exertion, with emphasis on motor speed and strength abilities (Barbero, 2006). Despite being linked to traditional football, due to the obvious characteristics it presents, it seems to be moving away to the sports that gave rise to it, conquering its own space (Amaral \& Garganta, 2005), being characterized as an intermittent sport has great physical, technical and tactical requirements for the player (Barbero, 2006; Soto et al., 2008).

Training of such motor skills is an important component of physical performance, and in this respect, more attention should be paid to the development of the specific physical training of these players. So, Futsal, like other team sports, involves a sequence of activities that mainly require anaerobic metabolism, (Cruz, 2010). From an organizational perspective, leadership, according to Chelladurai (2001), is only one of the roles to be carried out by a person who is to be responsible for a group, who carries out the activities, the orientations of the superiors and the purposes of the organization. Daronco and Flôres (2011) define leadership within a broader context as being the interpersonal influence exercised in a situation, through the communication process, to achieve a goal or several goals. Hersey and Blanchard (1986, p. 105) define leadership as "the process of influencing the activities of an individual or a group to achieve an objective in a certain situation". Leadership is defined as a process of influence, usually a person, through which an individual or group is oriented towards the establishment and achievement of goals.

It therefore consists of a relationship between people in which influence and power have been unevenly distributed on a legitimate basis, in a contractual or consensual form. Barbanti (2003) defines leadership as 
"the position and act of influencing people and groups to defined goals due to authority within the group or a social relationship". For him, this ability is based on personal prestige and is usually accepted by the leaders. Hunter (2004, p.25) defines leadership as "the ability to influence people to work enthusiastically to achieve the goals identified as being for the common good." In this context, which involves concepts and research on leadership, and considering its concept in a broader sense, as a subject of study in the field of social psychology, encompassing both sports and organizational processes. We highlight the approach of Soto (2008) which considers that "leadership appears as a phenomenon that acquires special interest for professionals who guide social groups to achieve maximum dedication and application in pursuit of a goal, seeking to meet needs of each member. Following this multidimensional perspective of leadership will be presented below theories and models of leadership within the sport context. Leadership involves the use of different forms of power to influence people's behaviour in different ways. Power refers to the ability to exert influence, that is, to change the attitudes or behaviour of individuals or groups, not simply from the level occupied in the organizational hierarchy (Casarin, 2010).

Wagner and Hollenbeck (1999) argue that the ability to exercise leadership is an attribute that the person uses in the form of power, being inherent and exercised by the leader according to the circumstance related to the leaders and the situation. According to Oliveira (2004), some authors define leadership as a process of conduct, through which some individual influences others to achieve what he wants. There is a consensus that leadership means the ability to influence people to work together in a harmonious way to achieve goals and objectives, it can be considered as an interpersonal process, which requires a high degree of interaction and is directly responsible for the motivation of the athletes (Chelladurai, 1984). An effective leader is a person who has the ability to influence others beyond what is normally expected of the authority position itse If (Fiorelli, 2001). The coaches have the crucial task of leading their athletes to a consistent performance even in the face of fatigue, pressure, opponents and different aspects of competition, fans, press and leaders (Brandão \& Carchan, 2010). The leader should get people together and move in the same direction. The emphasis is on establishing a vision, eliciting emotions and highlighting the values that lead to success. The leader is defined as an individual who is perceived by the group as the person best indicated in solving team problems. From this definition, it may seem that a sports team has several types of leaders at several levels, and the coach is a form of leader characterized by his great authority and responsibility (Papanikolaou, Patsiaouras \& Keramidas, 2005). But one or more members of the group may be able to take part in the leadership or assume it because of some implicit need of staff or staff to obtain status. For Dosil $(2004,231)$, the leader is "a person with a special charism that relates to the whole group and becomes a point of reference in any situation, being able to influence the thoughts, behaviours and feelings of the others. According to Barbanti (2003), the leader is "that individual who commands and exerts more influence than other members of the group and is in a position to make decisions that influence his actions and feelings. Hersey and Blanchard (1986) or Weinberg and Gould (2001) argue that leaders can be divided into two groups: democratic and autocratic. Democratic leader: Noce (2002, p.232), defines the democratic leader as the "individual who stimulates the group, putting the issues under discussion, describes the possible steps for achieving the goals, suggests alternatives and offers help". Weinberg and Gould (2001, p. 223) state that "within the sport context, coaches who adopt a democratic style are typically athletes centred, highly cooperative, and relationship oriented". Complementing this statement Hersey and Blanchard (1986) argue that these democratic leaders further accentuate their preoccupations with human relations. Autocratic leader: it is the one that determines the objectives to be reached by the group and uses its power to influence its subordinates, in addition to promoting the total exclusion of the ones led to any type of participation in the discussions. The authoritarian leader is one who has absolute power and fully absorbs the initiative of the group, concentrating in his person the capacities of planning, decision and control of the actions of the leaders (Samulski, 1992, Hersey \& Blanchard, 1986). Noce (2002) reveals that the authoritarian trainer performs 
better in situations in which he has great power or where he has no influence over the members of the group, because this definition in mind and evaluating the situational factors of sport this type of situation favours to taking of initiatives and decisions of the coach in relation to his team. Weinberg and Gould (2001) states that autocratic coaches are strongly structured and have as their main characteristics the orientation to victory and task execution. The area of leadership studies is quite broad, and its definition is always linked to the influence of one person on another or on a group so that they reach their goals (Lopes, 2008). The understanding of leadership varies according to the currents and the theoretical models, generating an academic number and that most applies to the sport. The most consensual definition in sports is from Weinberg and Gould (2001) that views leadership as a behavioural process of influencing individuals and groups towards the objectives. Leitão, Serpa and Bártolo (1995) and Alves (2000), also consider that the definition that can best be applied to sport is that, who considers sports leadership as a behavioural process that aims to influence subjects and / or groups to achieve the objectives set out above. Leadership implies a process of influence between the leader (coach) and his followers (athletes), all concepts can be approached from different perspectives (Mendo \& Ortiz, 2003). The leader, in the role of coach, must be able to relate to and establish links with his athletes, as well as contribute to the construction of an environment governed by fair and clear norms that do not oppose the organizational culture of the club. Lopes (2008) defines a sports team as a set of individuals who have a collective identity, share a common destiny, develop structural patterns of communication, manifest personal and task interdependence, as well as reciprocal interpersonal attraction, consider themselves constituents of a group and have the same goals and objectives. In this context, most technicians assume a certain style of leadership. Ideally, according to Luke (2001), it will be the leader to find an intervention model that helps athletes reach their full potential, both as executors and as social models, while respecting the rules and norms of fair competition. Chelladurai (1990) characterizes leadership as an interactional process in which the community of the leader in sport depends on circumstantial characteristics both of himself and of the group members. Therefore, effective leadership can and will vary depending on the characteristics of the athletes and the situation.

\section{MATERIALS AND METHODOLOGY}

\section{Objective}

Our study seeks to identify the leadership behaviours of the coaches as well as the players' perception and leadership preferences. We wish to identify the coach's leadership behaviours and be able to understand if what is perceived by the coach corresponds to the perception of the player and his preferences.

\section{Instruments}

The Leadership Scale in Sport (LSS) was used to analyse leadership behaviours and was developed by Chelladurai and Saleh (1978). The LSS was translated to Portuguese and validated by Serpa, Lacoste, Antunes, Pataco, and Santos. The LSS consists of 3 versions. One of the versions applied to the coach, in which he identifies his own Self-perception. The second version is directed to the athletes for their perception of the coach behaviour (perception). Finally, the version (preferences) that shows what athletes consider their ideal coach. The different questionnaires have 40 questions that are intended to describe the behaviour of the sports leader. In our investigation, the three questionnaires were used, one to be completed by the coach (version of the perception) and the other two by the players (perceptual version and preferences). The questionnaires assess the perception of training instruction behaviours, social support behaviours, reinforcement behaviours, autocratic and democratic behaviours. Their quotations are as follows: (100\% always $=5$ points $),(75 \%$ - frequently $=4$ points $),(50 \%$ - occasionally $=3$ points $),(25 \%$ - rarely $=2$ points $)$ and $(0 \%$ - never $=1$ point $)$. 


\section{Participants}

The participants of our study consisted of two coaches and 26 players, 12 of them in the "Under 17" level, with ages between 15 and 17 years, and 14 senior players, aged between 18 and 33 years of age. Participants were athletes and coaches at the Vitoria Clube Santarém club, a team of the national first league, and all of them gave their informed consent in writing.

\section{Procedures}

For a viable application of the questionnaires, they were delivered to all participants 30 minutes before the training. All questions were clarified to the athletes and coaches regarding the interpretation of the questions. After completing the questionnaires, they were collected and coded for further analysis.

\section{Statistical Procedures}

This is a descriptive and inferential study, after the Kolmogrov-Smirnov test, the normality assumptions in the data distribution were fulfilled, we chose parametric statistics, using the T-Test to analyse the differences between the different variables.

\section{RESULTS}

In the following tables we present the results obtained from the evaluations. We identified in table 1 the means and standard deviation of the self-perception of the senior coach as well as the perception of his players. The Training Instruction and Reinforcement dimensions present the highest values. The lowest dimension is the Autocratic.

Table1. Mean of Coach Self-perception and Seniors players perceptions

\begin{tabular}{cccc}
\hline & Coach Senior & \multicolumn{2}{c}{ Players $(\mathrm{N}=14)$} \\
\hline Mraining Instruction & Mean & Mean & SD \\
Social support & 4,15 & 4,28 & 0,5 \\
Reinforcement & 3,25 & 3,73 & 0,6 \\
Democratic & 3,6 & 4,2 & 0,73 \\
Autocratic & 3,56 & 3,61 & 0,44 \\
\hline
\end{tabular}

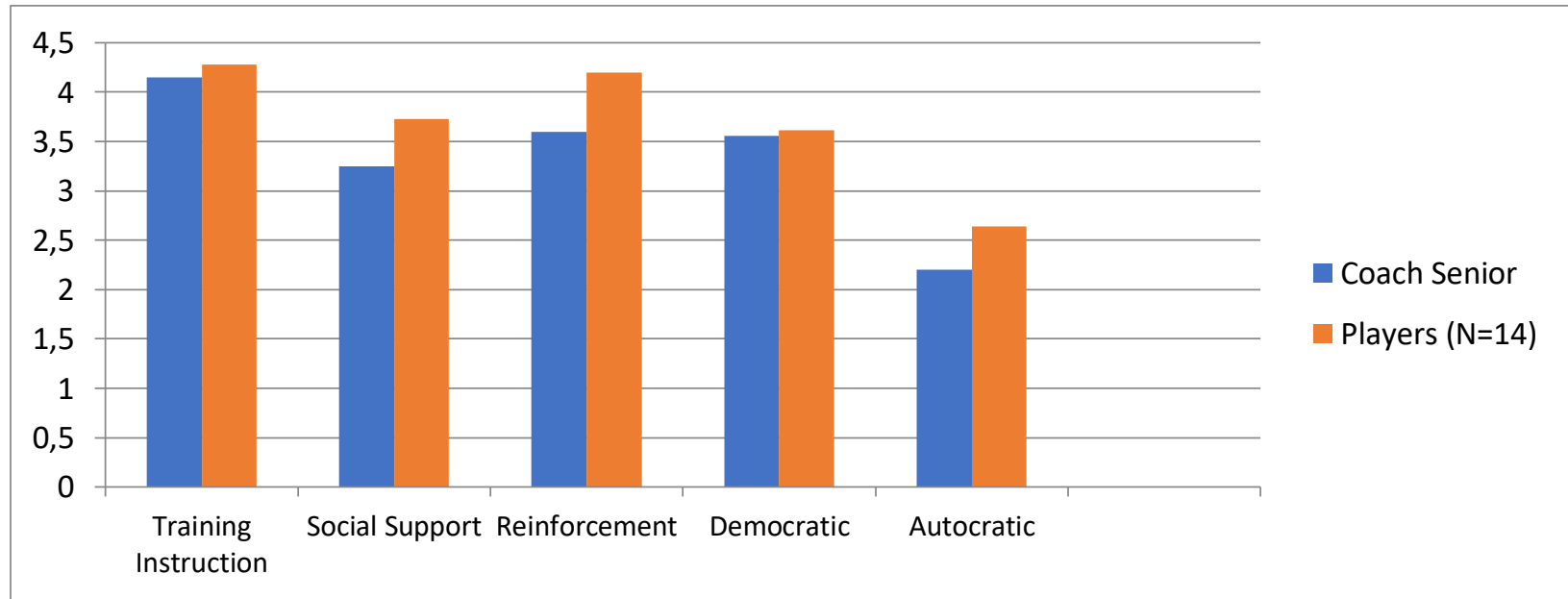

Figure 1. Mean of Coach Self-perception and Seniors players perceptions 
In the next table we present the means and standard deviation of the self-perception of the "Under 17" coach as well as the perception of his players. The Training Instruction and Reinforcement dimensions present the highest rates. The lowest dimensions are the Democratic and Autocratic.

Table 2. Mean of Coach Self-perception and "Under 17" players perceptions

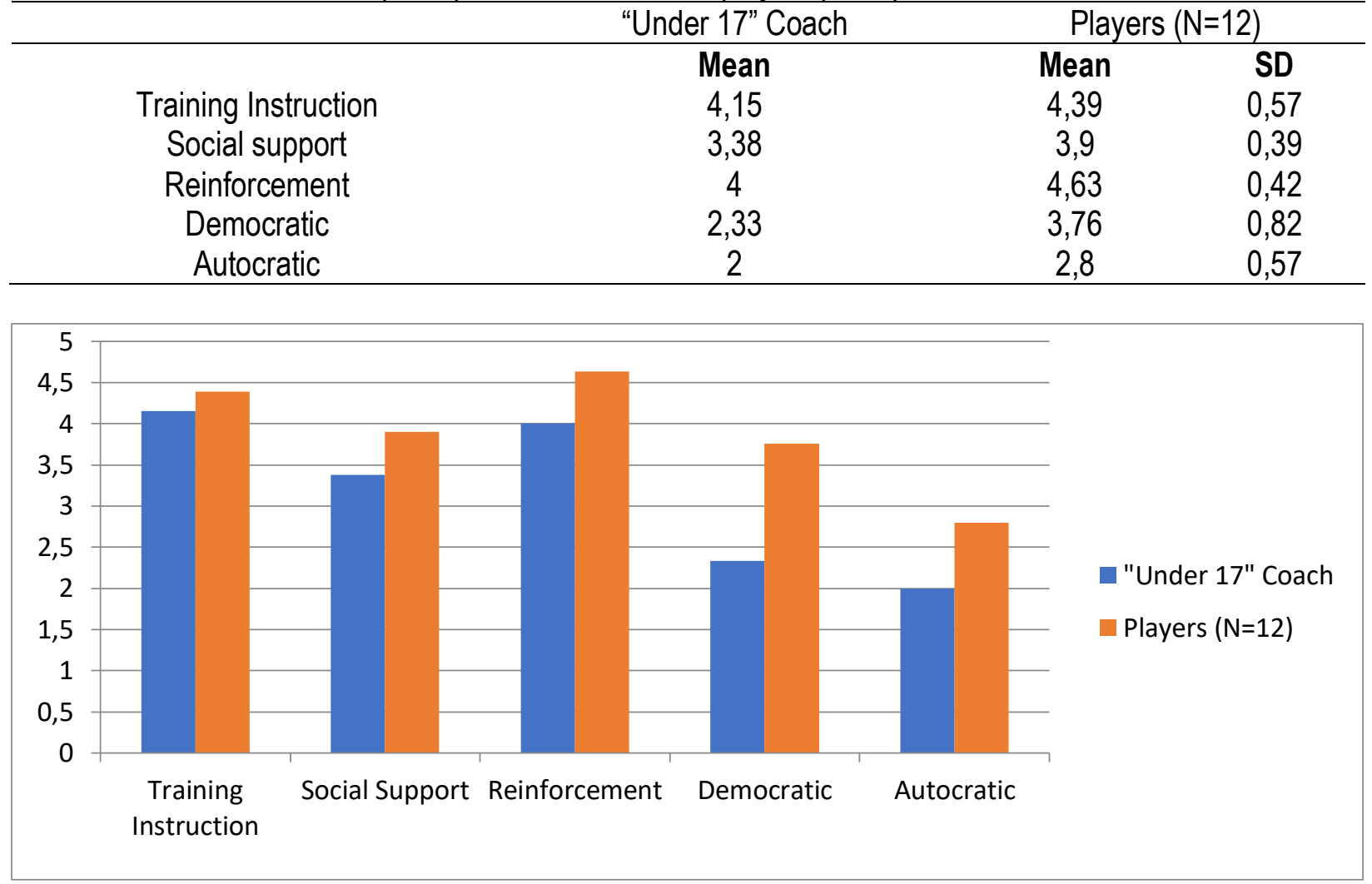

Figure 2. Mean of Coach Self-perception and "Under 17" players perceptions

In the table below we present the means and standard deviation of the self-perception of the senior coach as well as the preferences of his players. The Training Instruction and Reinforcement Training present the highest means. The lowest dimensions are Social Support and Autocratic.

Table 3. Mean of Self-perception and Preferences of Seniors players

\begin{tabular}{cccc}
\hline & Coach Senior & \multicolumn{2}{c}{ Players $(\mathrm{N}=14)$} \\
\hline & Mean & Mean & SD \\
Training Instruction & 4,15 & 4,65 & 0,4 \\
Social support & 3,25 & 3,9 & 0,63 \\
Reinforcement & 3,6 & 4,41 & 0,72 \\
Democratic & 3,56 & 4,2 & 0,4 \\
Autocratic & 2,2 & 3,17 & 0,83 \\
\hline
\end{tabular}




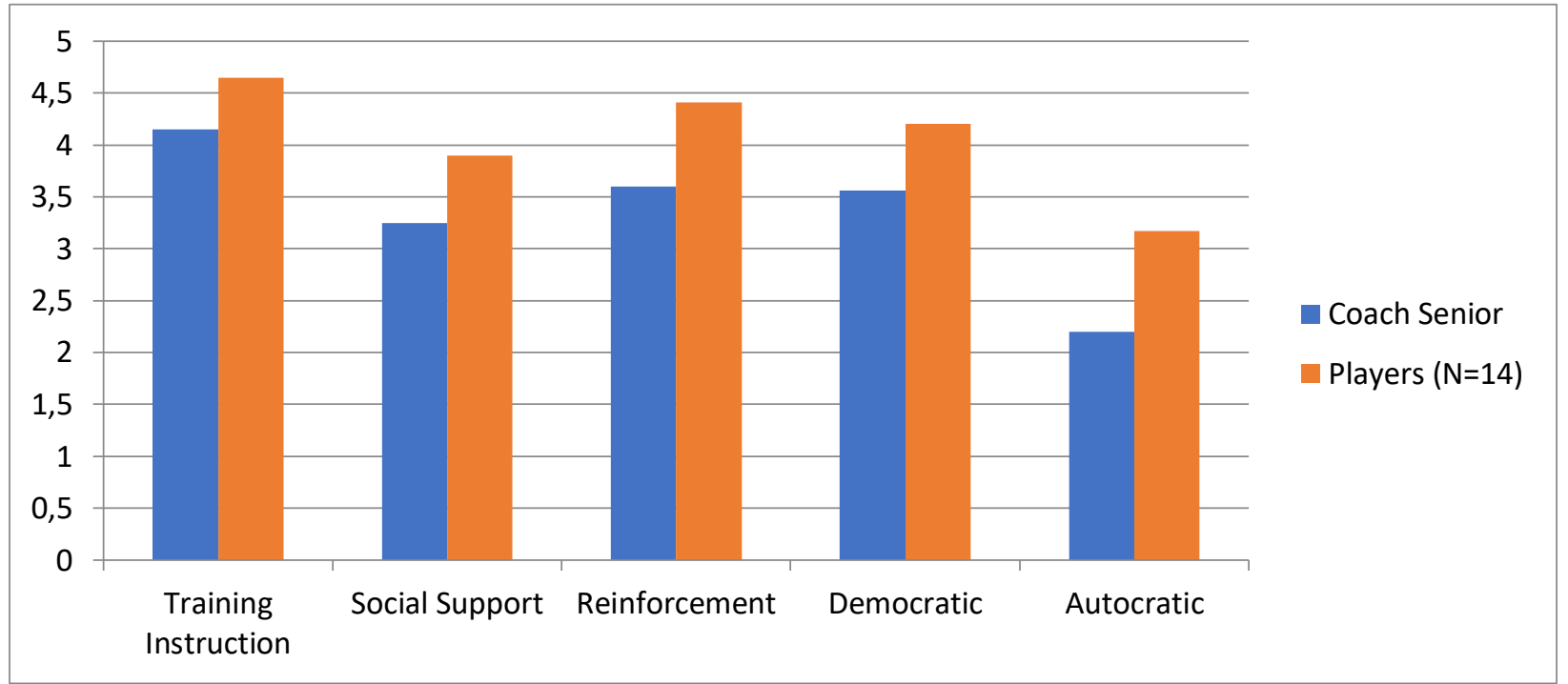

Figure 3. Mean of Self-perception and Preferences of Seniors players

In the next table are presented the means and standard deviations of the Self-perception of the "Under 17" coach as well as the preferences of his players. The Training Instruction and Reinforcement dimensions present the highest values. The lowest dimensions are the Democratic and Autocratic.

Table 4. Mean of Self-perception and Preferences of "Under 17" players

\begin{tabular}{cccc}
\hline & "Under 17" Coach & \multicolumn{2}{c}{ Players (N=12) } \\
\hline & Mean & Mean & SD \\
Training Instruction & 4,15 & 4,39 & 0,57 \\
Social support & 3,38 & 3,9 & 0,39 \\
Reinforcement & 4 & 4,63 & 0,42 \\
Democratic & 2,33 & 3,76 & 0,82 \\
Autocratic & 2 & 2,8 & 0,57 \\
\hline
\end{tabular}

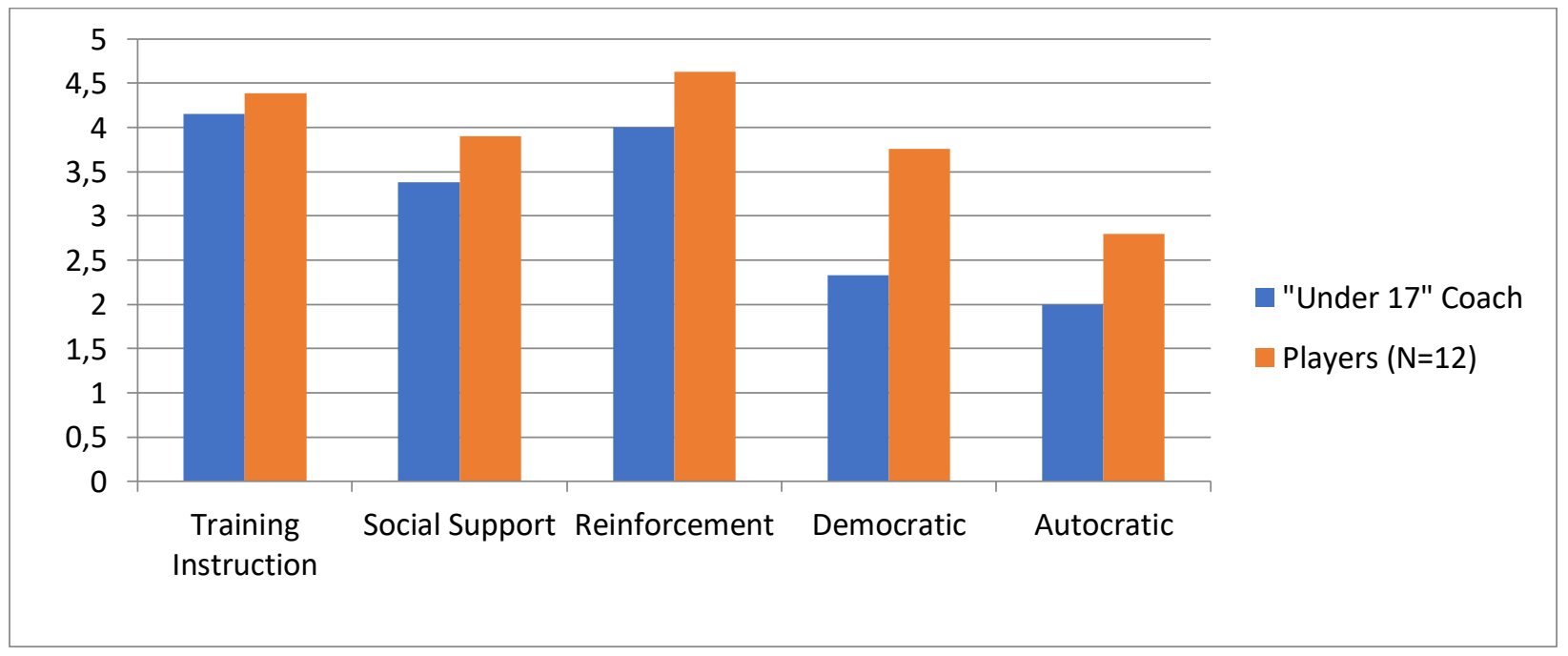

Figure 4. Mean of Self-perception and Preferences of "Under 17" players 
In the table 5 we present the means of Perception of the five dimensions considered to these different levels. With these results, we can affirm that there are no significant differences in the results obtained.

Table 5. Mean of perceptions between players levels

\begin{tabular}{ccccccc}
\hline Variables & Level & N & Mean & SD & $\mathbf{Z}$ & $\boldsymbol{p}$ \\
\hline Training Instruction & "Under 17" & 12 & 4,39 & 0,57 & 0,075 & 0,606 \\
& Senior & 14 & 4,28 & 0,5 & & \\
& "Under 17" & 12 & 3,9 & 0,39 & 2,831 & 0,411 \\
Social support & Senior & 14 & 3,73 & 0,6 & & \\
& "Under 17" & 12 & 4,63 & 0,42 & 1,573 & 0,074 \\
& Senior & 14 & 4,2 & 0,73 & & \\
Reinforcement & "Under 17" & 12 & 3,76 & 0,82 & 4,698 & 0,582 \\
& Senior & 14 & 3,61 & 0,44 & & \\
Democratic & "Under 17" & 12 & 2,8 & 0,57 & 0,999 & 0,509 \\
Autocratic & Senior & 14 & 2,64 & 0,62 & & \\
& & & & & & \\
& & & & &
\end{tabular}

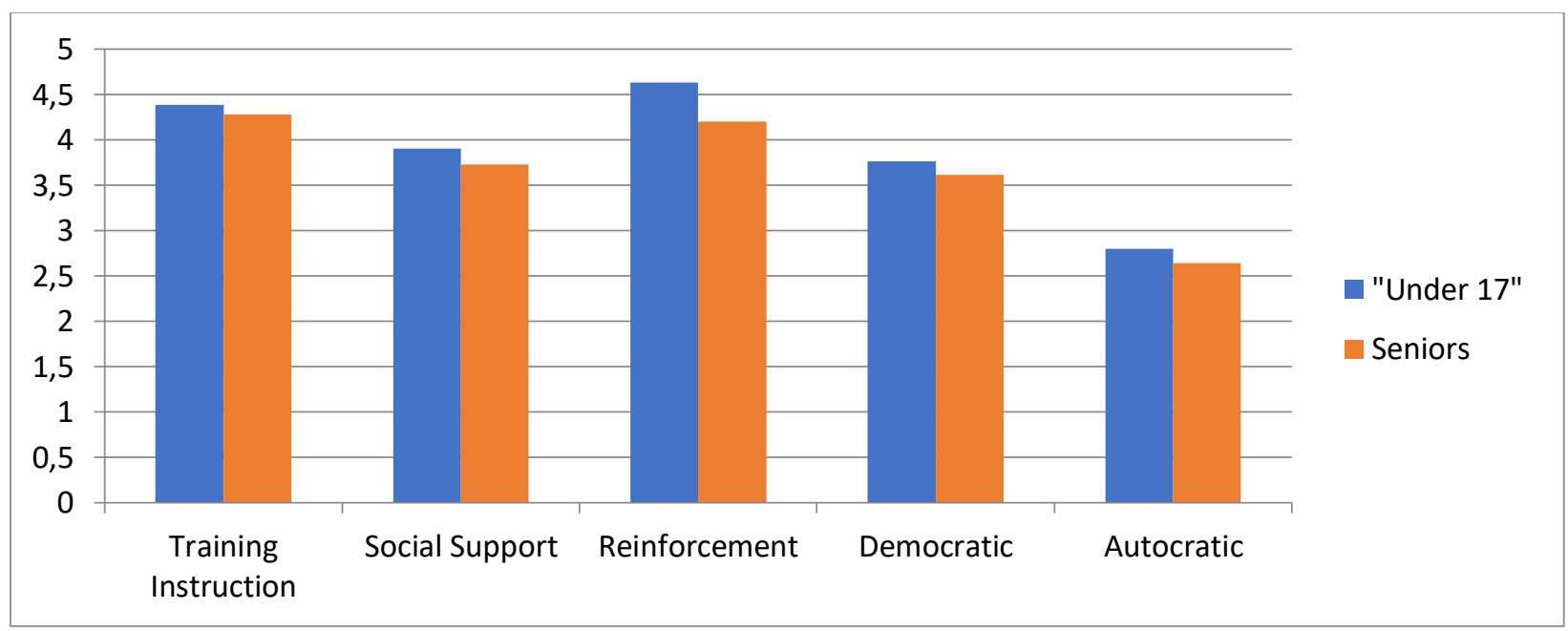

Figure 5. Mean of perceptions between players levels

In the table below we present the averages of the Preferences of the five dimensions considering the different levels. According to these results, we can confirm that there are no significant differences in the results obtained.

Table 6. Mean of preferences between players levels

\begin{tabular}{ccccccc}
\hline Variables & Level & $\mathbf{N}$ & Mean & SD & Z & p \\
\hline \multirow{2}{*}{ Training Instruction } & "Under 17" & 12 & 4,71 & 0,3 & \multirow{2}{*}{0,779} & 0,679 \\
& Senior & 14 & 4,65 & 0,4 & & \\
Social support & "Under 17" & 12 & 4,06 & 0,5 & 0,521 & 0,477 \\
& Senior & 14 & 3,9 & 0,63 & & \\
Reinforcement & "Under 17" & 12 & 4,82 & 0,23 & \multirow{2}{*}{4,507} & 0,066 \\
& Senior & 14 & 4,41 & 0,72 & &
\end{tabular}




\begin{tabular}{ccccccc}
\hline \multirow{2}{*}{ Democratic } & "Under 17" & 12 & 4,01 & 0,61 & \multirow{2}{*}{1,267} & \multirow{2}{*}{0,359} \\
& Senior & 14 & 4,2 & 0,4 & & \\
Autocratic & "Under 17" & 12 & 2,85 & 0,68 & \multirow{2}{*}{0,204} & \multirow{2}{*}{0,288} \\
\hline
\end{tabular}

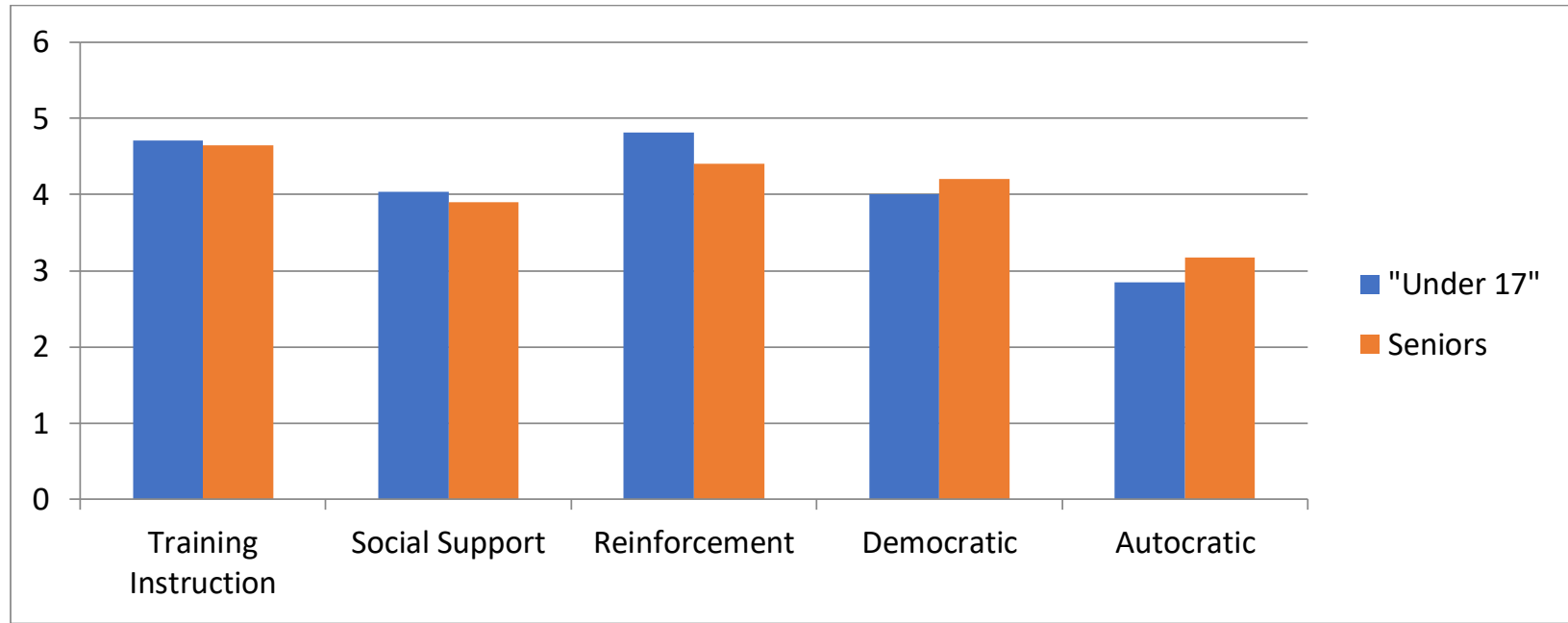

Figure 5. Mean of perceptions between players levels

\section{DISCUSSION}

After analysing these results, we verified that the perception of the leadership in these different levels did not show significant differences. The values of the highest dimensions are Training Instruction and Reinforcement. The Dimension that presents lower values is the Autocratic. Regarding the variable "The Leadership Preferences will differ in the different levels," in which the results obtained do not demonstrate significant differences and the dimensions with higher rates are again the Training Instruction and Reinforcement and the dimension with lower values is also the Autocratic. In these both levels are given preference to the Democratic with higher values.

From the descriptive analysis of the 5 dimensions, we verified through the results that "The Perception of Leadership will correspond to the Self Perception of the Coach", did not reveal correspondence but pre sent similarities in the values obtained between the perception of the players and the Self-perception. However, it should be noted that the coaches positively increase the Training Instruction and Reinforcement dimensions in both levels, and the dimension with the lowest quotation is the Autocratic in both levels as well. In the variable "Leadership preferences will correspond to the coach's self-perception", where the data do not correspond in which the value with the greatest discrepancy is the Autocratic dimension in the senior coach and the Democratic dimension in the "Under 17" group. Both levels give more importance to the Training Instruction dimension in which the values have a very low discrepancy compared to the one of their coach.

\section{CONCLUSIONS}

According to our study we can conclude that:

The senior level has a leadership perception very similar to their coach in all dimensions, different from the "Under 17" players that already shows different results. Both levels give high importance to the dimensions 
of Training Instruction and Reinforcement, having them as the main preferences and the same ones agree that the Autocratic dimension is the preference with lower quotation. For future works, it would be interesting to explore different topics, such as gender self-perception of coaches', increase the number of participants to obtain more meaningful data considering these kind of studies, and it would be interesting to try to perceive the differences of a leadership in a feminine and masculine context, comparing them in a sport context independently of the kind of sport.

\section{REFERENCES}

Amaral \& Garganta (2005). A modelação do jogo em Futsal. Análise sequencial do 1x1 no processo ofensivo. Revista Portuguesa de Ciências do Desporto, 3, 298-310.

Barbanti, V. (2003). Dicionário de Educação Física e do Esporte. Brasil: Edições Manole.

Barbero, J. (2006). Relación entre el consumo máximo de oxígeno y la capacidad para realizar ejercicio intermitente de alta intensidad en jugadores de Fútbol Sala. Revista Entrenamiento Deportivo, 6, 3544.

Brandão, M., \& Carchan, D. (2010). Comportamento preferido de liderança e a sua influência no desempenho dos atletas. Motricidade, 6, 53-69. https://doi.org/10.6063/motricidade.6(1).158

Adriano, N. (2003). Planificação de treino para o futsal - Uma nova filosofia. Revista Digital, № 59.

Bellarte, M. (2013). Os Princípios Tácticos no Futsal. On-line in http://www.bellartefutsal.com/index.php?lang=it

Braz, J. (2006). Organização do jogo e do treino em futsal. Tese de Mestrado: Faculdade de Desporto. Universidade do Porto, Porto.

Benevides, V. (2010). Os Estilos de Liderança e as principais tácticas de influência utilizadas pelos líderes Brasileiros. Rio de Janeiro: Edições Escola Brasileira de Administração Pública e de Empresas.

Casarin, R. \& Oliveira, R. (2010). Periodização táctica: princípios estruturantes e erros metodológicos na sua aplicação no futebol. Revista Digital, N0144.

Castelo, J. (1996). Futebol a Organização do Jogo. Lisboa: Edições FMH.

Castelo, J. (2002). O Exercício de treino desportivo. A Unidade lógica de programação e estruturação do treino desportivo. Lisboa: Edições FMH.

Castelo, J. (2003). Futebol-Actividades Físicas e Desportivas. Edições FMH. Universidade Técnica de Lisboa.

Chelladurai, P. \& Saleh, S. (1978). Preferred leadership in sports. Canadian Journal of Sport Science,3,85-92.

Chelladurai, P. (1999). Human Resource Manegemant in Sport and Recreation. Illinois, Human Kinetics.

Cid, L. (2006). Liderança no Desporto. Tentando simplificar um processo complexo. Tese de Mestrado: Rio Maior. Escola Superior de Desporto de Rio Maior.

Costa, M. (2010). As Competências Psicológicas no Desporto: estudo caso de Selecções Distritais de Futebol e Futsal. Lisboa: Edições FMH.

Costa, V. (2003). Análise do perfil de liderança actual e ideal de treinadores de futsal de alto rendimento, através da escala de liderança no desporto. Tese de Mestrado: Belo Horizonte. Universidade Federal de Minas Gerais.

Cruz, R., Pellegrinoti, Í., Oliveira, R. \& Lopes, G. (2010). Parâmetros morfológicos e neuro motores em atletas de futsal de diferentes categorias. Revista Digital, $N^{0} 148$.

Daronco, L. \& Flôres, F. (2011). Los fundamentos técnicos: la base del futsal; Revista Digital, № 163.

Dias, R. (2011). Caracterização Fisiológica de Atletas Seniores de Futsal. Tese de Mestrado: Faculdade de Ciências do Desporto e Educação Física. Universidade de Coimbra, Coimbra. 
Dosil, J. (2004). Psicología de la Actividad Física y del Deporte. Madrid: Ediciones McGraw Hill.

Ferreira, M. (2008) Eficácia de Liderança em Treinadores de Futsal. Tese de Mesatrdo: Faculdade de Desporto, Universidade do Porto, Porto.

Fiorelli, J. (2001). Psicologia para Administradores: Integrando Teoria e Prática ( $2^{a}$ ed.). São Paulo: Edições Atlas.

Gomes, R. (2005). Liderança e relação treinador-atleta em contextos desportivos. Tese de Mestrado: Universidade do Minho, Braga.

Hersey, P. \& Blanchard, K. (1986). Psicologia para administradores: a teoria eas técnicas da liderança situacional. São Paulo: Editora Pedagógica e Universitária.

Hunter, J. (2004). O monge e o executivo: uma historia sobre a essência da liderança. Rio de Janeiro: Edições Sextante.

Luke, M. (2001). Treinar a liderança ou a liderança no treino... ou ambas. Revista Treino Esportivo, 114, $112-124$.

Mendo, A. \& Ortiz, J. (2003). El Liderazgo en los Grupos Deportivos - Psicología del Deporte. Buenos Aires: Tulio Guterman Editora.

Morais, A. (2011). Uma equipa júnior de futsal em evolução. Tese de Doutoramento: Universidade Lusófona de Humanidades, Lisboa.

Noce, F. (2002). Liderança. Psicologia do Esporte. São Paulo: Editora Manole.

Oliveira, P. (2008). Amplitude e Profundidade dos Sistemas de Jogo em Futsal. Tese de Mestrado: Faculdade de desporto, Universidade do Porto, Porto.

Oliveira, V. \& Paes, R. (2004). A pedagogia da iniciação esportiva: um estudo sobre o ensino dos jogos desportivos colectivos. Revista Digital, $N^{0} 71$.

Papanikolaou, Z.; Patsiaouras, A.; Keramidas, P. (2005). Leadership behaviour of the coach in amateur soccer teams. Science and football V. The proceedings of the Fifth World Congress on Science and Football. London: Routledge.

Paquete, M. (2009). Liderança de Equipas Desportivas. Tese de Doutoramento: Faculdade de Desporto, Universidade do Porto, Porto.

SamPedro, J. (1998). Futbol - Sala- Las acciones del juego. Analices metodológico de los sistemas de Juegos. Madrid: Ediciones Gymnos.

Soto (2008) Effect of match-related fatigue on shortpassing ability in young soccer players. Medicine and Science in Sports and Exercise, 5, 934-942.

Teodorescu, L. (1984). Problemas da Teoria e Metodologia nos desportos colectivos. Lisboa: Edições Livros Horizonte.

Travassos, B. \& Araújo, D. (2005). Exercício de treino - Mais do que uma repetição... uma oportunidade para inovar. Documento de Apoio: Universidade da Beira Interior, Covilhã.

Wagner e Hollenbeck (1999). Comportamento organizacional: criando vantagem competitiva. São Paulo: Edições Saraiva.

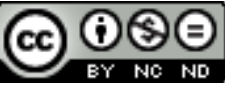

This title is licensed under a Creative Commons Attribution-NonCommercial-NoDerivs 4.0 Unported License. 